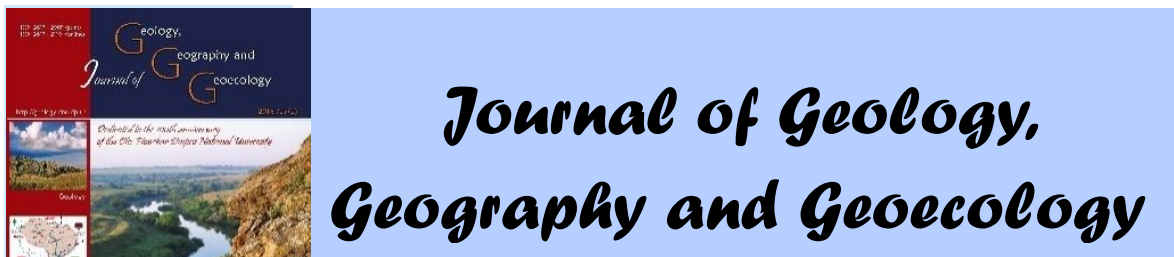

\title{
Analysis of geoecological problems of Dnipropetrovsk region (in multidimensional sign space)
}

\author{
V.V. Hrushka, N.A. Horozhankina, Z.V. Boiko \\ ${ }^{1}$ Oles Honchar Dnipro National University, e-mail:Grush_vv@ua.fm, \\ Nataliagorozhankina@gmail.com,Zdor_zv@ukr.net
}

\author{
Received 12.12.2018; \\ Received in revised form 16.01.2019; \\ Accepted 19.02.2019
}

\begin{abstract}
The generalized statistical data on changes in the indexes of statistical parameters of the investigated process in time and on sociogeosystems is calculated and given. According to the results of the analysis of the dynamics of the indexes of the statistical parameters of the development of the geoecological situation in urban and district sociogeosystems, it has been established that for the entire study period (2013-
\end{abstract} 2017) the largest number of positive changes (growth) of parameters was noted for the cities of Pavlograd, Novomoskovsk and Sinelnikove. The largest number of negative changes (diminishing) of parameters was noted for the cities of Dnipro, Vilnogirsk, Nikopol and Kam'yanske. These data characterize the stability of the dynamics of the geoecological situation in cities. It was determined that the district sociogeosystems are even more differentiated by changing the indices of statistical parameters of the development of the geoecological situation in comparison with the urban ones. More positive changes are characteristic for Novomoskovsk, Krynichansky, Mezhivskyy, Shirokivsky and Vasylkivsky districts; the majority of the negative - forApostolivsky, Pavlogradsky, Petropavlivsky, Pyatihatsky and Yurievsky districts. The statistical analysis of changes in the indexes in the context of the calculation periods gave reason to assert the existence of rather complex and contradictory time patterns of the development of the geoecological situation in the district sociogeosystems, but in the vast majority of cases they coincide with the results of modeling the trajectory of the process. The analysis of changes in the indices of statistical parameters of the geoecological situation for each city and district sociogeosystem has allowed us to group the parameters by the frequency of positive and negative changes. The classification of the development of the geoecological situation in the sociogeosystems is carried out on the criterion of the sum of codes of changes in the indexes of statistical parameters. The calculated sum of the codes of changes of the indexes of parameters for each sociogeosystemmakes it possibleto purposefully manage the process of formation and development of the geoecological situation in the sociogeosystems. A similar analysis was carried out for all parameters of the development of the geoecological situation, which showed that according to the dynamics of the indices, they differ significantly for cities and districts.

Keywords: old industrial region, geoecological situation, multidimensional sign space, sociogeosystem, environment.

\section{Аналіз геоекологічних проблем Дніпропетровської області (у багатовимірному ознаковому просторі)}

\section{В.В. Грушка, Н.А. Горожанкіна, 3.В. Бойко}

${ }^{1}$ Дніпровський наиіональний університет імені Олеся Гончара, Дніпро, Україна, e-mail: Grush_vv@ua.fm, Nataliagorozhankina@gmail.com,ZZdor_zv@ukr.net

Анотація. За результатами аналізу динаміки індексів статистичних параметрів розвитку геоекологічної ситуації в міських $\mathrm{i}$ районних соціогеосистемах встановлено, що за весь досліджуваний період (2013-2017 рр.) найбільшою кількістю позитивних змін (зростанням) параметрів характеризуються міста Павлоград, Новомосковськ і Синельникове; найбільшою кількістю негативних змін (зменшенням) параметрів відрізняються міста Дніпро, Вільногірськ, Нікополь і Кам'янське. Ці дані характеризують стійкість динаміки розвитку геоекологічної ситуації в містах. Для районів вказані тенденції більш строкаті. Більше позитивних змін характерні для Новомосковського, Криничанського, МежівськогоШироківського i Васильківського районів; більшість негативних - для Апостолівського, Павлоградського, Петропавлівського, П’ятихатського і Юр’ївського районів. Виконаний для кожної міської і районної соціогеосистем аналіз змін 
індексів статистичних параметрів розвитку геоекологічної ситуації дозволив згрупувати параметри за частотою позитивних і негативних змін. Здійснена класифікація розвитку геоекологічної ситуації в соціогеосистемах за критерієм суми кодів змін індексів статистичних параметрів. Розраховані суми кодів змін індексів параметрів для кожної соціогеосистеми дозволяють цілеспрямовано управляти процесом формування і розвитку геоекологічної ситуації в соціогеосистемах. Аналогічний аналіз виконано для всіх параметрів розвитку геоекологічної ситуації, який показав, що за динамікою індексів вони суттєво відрізняються для міст і районів.

Ключові слова: старопромисловий регіон, геоекологічна ситуація, багатовимірний ознаковий простір, соиіогеосистема, навколишнє природне середовище.

Introduction. Geoecological problems of Dnipropetrovsk region, as an old industrial region (OIR), in the vast majority of cases are not specific, because they are characteristic of all OIR. They are generated by one ideologically deterministic goal the achievement of the highest possible level of industrial development and production at any price. At the same time, the opinions and interests of the population, the deterioration of living conditions, quality of life, etc., were practically ignored. Health risks and difficult working conditions were offset by relatively high wages and other benefits. As a result, much of the working population paid for high earnings with their own health, and the health of their families did not interest anyone.

Ukraine's environmental problems at the proclamation of independence can be set against a background of a number of transitional social, economic, and psychological problems. The problem of social adaptation of the general population to new social conditions, the loss of habitual social orientations, the change of spiritual and moral values, introduction of fundamentally new production relations and demands, impoverishment, loss of work, etc. - all this reduced the overwhelming majority of people to a harsh struggle for survival, the most important priority being to get the opportunity to feed one's family and protect it from hardships.Geoenvironmental issues have lost relevance in the public consciousness. The stoppage of many enterprises with harmful production somewhat changed the geoecological situation for the better, but this was not the result of a radical change in government policy in the field of environmental impact. Unfortunately, the principles of democracy, social justice and care for every person, which are declared as founding principles of an independent and sovereign Ukraine, have not been introduced into public life.As a result, the geoecological problems of the OIR remained unresolved, and the new generation of Ukrainians continues to suffer from a contaminated atmosphere, lack of clean water and environmentally friendly food (K. Niemets, L. Niemets, 2011).

It cannot be argued that today the central and local authorities ignore the problem of improving the geoecological situation in the regions. In spite of the difficult financial and economic state of the country, geoecological research is carried out at all levels from national to local, and corresponding comprehensive programs of socio-economic development are developed and funded, in which problems of the quality of the environment are considered, measures are being planned and implemented to improve its state .Yet, in our opinion, all this important and responsible work is not conducted in a sufficiently systematic and complex manner. In particular, the issues of social development and the formation of the geoecological situation in the region are insufficiently associated, the dependence of the level and quality of life of the population on the state of the geoecological situation is poorly studied. On the one hand, this can be explained by the lack until recently of a sufficiently powerful social demand for such research, because public attention is more focused on socio-economic and political issues. On the other hand, traditional methodological approaches (economic, sociological, geoecological, etc.) alone do not provide a truly comprehensive coverage of the problem as a whole, and are configured to obtain local, narrowly specialized results. The declared comprehensiveness of the justification of the programs is, in fact, the result of the mechanical combination of these approaches without a meaningful change in the research. We are convinced that today only the socio-geographical approach is adequate to the problem being studied and capable of providing a comprehensive study and solution. An example of such an approach in the Dnipropetrovsk region is the work (Shy'yan, 2012), devoted to the study of morbidity of the population of Kryvyi Rih city focused on ecologically determined diseases.

Materials and methods of research.Real results on the improvement of the geoecological situation in the OIR, including in Dnipropetrovsk region, can only be achieved on the basis of awareness of society that the highest priorities should be the level and quality of human life. This means that the main criterion of maturity of society, its orientation and readiness to meet true human values, is the spiritual, moral and material comfort of people's lives. 
A detailed, meaningful analysis of the state of sociogeosystems (SGS) for a given time period in a multidimensional sign space (MSS) is needed to clarify and explain the dynamics of the geoecological situation, for which we used the component analysis of the development vector. The idea is based on the definition of the vector of development projections on each axis of the MSS, followed by an analysis of their changes. This makes it possible to move from the general assessment of the development of SGSs in an integral form to the assessment of individual components (parameters of the socio-geographical process), which makes sense, for example, in solving planning tasks, forecasting and optimizing development, managing them (for example, in the context of the implementation of the concept of sustainable development), resource management development, etc. It is important to know the fate ("contribution") of each parameter in the overall development of sociogeosystems and to find the "bottlenecks" of this process for precise targeting (Niemets, Grushka, 2014).

The above method is realized in a normalized MSS, which is formed by a set of statistical parameters of the studied SGS. Rationing (indexing) of parameters is performed according to the formulas:

$$
I_{i, j}=\frac{X_{i, j}-X_{\min , j}}{X_{\max , j}-X_{\min , j}}
$$

for indicators that characterize positive processes in a SGS, and

$$
I_{i, j}=1-\frac{X_{i, j}-X_{\min , j}}{X_{\max , j}-X_{\min , j}}
$$

for indicators of negative processes.

Indication in the following formulas:

$\mathrm{Ii}, \mathrm{j}$ - index of the current $\mathrm{j}$-th parameter;

$\mathrm{j}=1,2,3$;

$\mathbf{m}$-number of parameters; $\mathrm{i}=1,2,3$;

$\mathbf{n}$ - number of SGS;

$X_{i, j}$ - current value of $\mathrm{j}$-th parameter;

$X_{\text {max }, j}$ - is the largest value of the $\mathrm{j}$-th parameter in a series of observations;

$X_{\min , j}-$ is the smallest value of the $\mathrm{j}$-th parameter in a number of observations.

As a result, all calculated indices, regardless of the dimension and absolute values of the initial parameters, are dimensionless and vary in the range from 0 to 1.
The normalized MSS thus formed is a hypercube, each edge of which has a length of 1 unit, and the dimensionality by the number of output statistic is $\mathbf{m}$. In the hypercube of a MSS, there are two distinct points that are very important for further analysis. The first of these is the point of minimal development - coincides with the origin of coordinates, where all coordinates of the MSS are zero.The second one is the point of maximum development - the opposite of the main diagonal and has all the coordinates equal to one. The main diagonal of the hypercube, which connects these two points, is the optimal trajectory of development (OTD), that is, the ideal trajectory on which the SGS can achieve the maximum possible development in the shortest possible way. It should be emphasized that the OTD is an abstraction and cannot be realized by any real SGS, but it is a convenient benchmark for comparing real trajectories of SGS.

The trajectory of the development of the SGS in a MSS is formed by a set of vectors that connect the time-consistent points of the location of the SGS in a MSS. By analogy with mechanical motion, the change in the statistical parameters of the SGS in time (that is, the change in its location in the MSS) is considered as a movement in a MSS. For analysis of the trajectory, a mathematical apparatus for vector analysis is used, according to which any vector in space has two determinant characteristics - angular and linear. The angular parameter of the vector determines its direction in space, which is determined through the guide cosines, and the linear one is the length of the vector, which is defined as the Euclidean distance between its initial and final points (Niemets, 2009).

In socio-geographical research it is important to know not the parameters of the vector of motion of SGS, but their relations (comparisons) with the corresponding parameters of other SGS or characteristic directions in the MSS. Such directions are the OTD (the main diagonal of the hypercube), the average for the totality of SGS of the trajectory, the trajectory of development of other SGSs of one hierarchical level (consistency of motion of SGS), the planned or projected trajectory (in the tasks of management and optimization), etc.

Different ratios of linear parameters of vectors characterize various indicators of development of an SGS, for example, speed of motion (dynamics of development), deviations from the comparable trajectory, projection of the real trajectory to the optimal or design, etc. An important indicator of the development of an SGS is the projection coefficient of progress, which is the ratio of the projection of the vector of motion of 
the SGS to the optimal trajectory of motion to the length of the latter; its limiting value is equal to one.

Methods of multidimensional classification on the level and state of development of SGSs in the research are represented by the graph-analytical method (Mashkov, Niemets, 2010). It is based on the idea of projection of a MSS on a plane and in the form of a petal diagram, constructed on the set of normalized coordinate axes. Each SGS is represented in the form of a polygon, the shape and dimensions of which are its quantitative characteristics. In this method, the criterion of classification and the system development indicator for comparative analysis is the area of the polygon on the petal diagram.

From the point of view of mathematics, this problem is reduced to the calculation of the time derivatives of each process parameter for the corresponding calculation periods of time and in principle has two variants of the solution: qualitative and quantitative. A qualitative solution involves determining only the sign of the time derivative, that is, establishing the fact of qualitative change of the parameter (increases, decreases or unchanged) with the subsequent encoding of the event on the nominal scale. A quantitative solution consists in determining not only the sign, but also the value of the derivative, which gives a more accurate assessment of the event on the relative scale, and requires the use not of indexes but the output (measured) values of the parameters. The fact is that the procedure for calculating the indexes is constructed in such a way that, regardless of the content of the parameter (positive - characterizes growth or negative - a decrease in the characteristics or quality of the process) the indexes are uniquely determined as directly proportional to the growth of the sign or quality of the process.For example, the "negative" indicator - the mortality rate of the population has an index whose increase corresponds to a decrease in the indicator (Shablij, 1994). In this article we confine ourselves to describing only the qualitative solution of the problem, as the most general one.

In calculating the time derivative there are three possible results:

1) if the parameter during the calculation period remained constant, which means that the process under this parameter is stable, the derivative is equal to 0 and it is expedient to assign code 0 to such result;

2) if the parameter decreases, that is, the process is regressed after it, the derivative will be negative, and the result code -1 ;

3 ) as the parameter increases, when the process progresses after it, the derivative will be positive and the result code +1 .
The proposed selection of time source codes (divided into three groups on a nominal scale) is convenient in terms of their further processing. Thus, in the aggregate of the indexes of statistical parameters of the development process of the geoecological situation, it is enough to calculate the sum of the codes of the derivatives of the corresponding groups, which will quantitatively characterize changes in the parameters for the calculated period of time, and the total amount of codes will show which parameters of change prevail. In the general study of processes, qualitative analysis is sufficient for a general evaluation of the process of changes in components of the vector of development. When solving application problems of controlling the process, optimizing it, monitoring or forecasting, a quantitative component analysis is needed, which identifies specific corrective changes in the control parameters of the process.

Results and their analysis.Due to the large volume of tabular material, it is impossible to present all the results of calculations in the article; therefore, we will explain that the estimated data of our study reflect changes in the indices of statistical parameters of the development of the geoecological situation in the SGSs. In particular, it is evident according to whichparameters a certain sociogeosystem progresses, and according to which it regresses. Such a detailed analysis of the dynamics of the development of the geoecological situation in sociogeosystems makes it possible to respond promptly to all changes in the flow of the process and make timely corrections (Golovne, 2018, Dnipropetrovs`ka, 2018).

Before proceeding to the examples of analysis of the development process of the geoecological situation in a particular SGS, it should be noted that the statistical analysis of the sum of the indices of parameters of this process also gives interesting and useful results. On the one hand, these results obtained by other methods, in most cases, confirm the results of the analysis of the systemic development of the geoecological situation in the SGS discussed above. This serves as proof of the reliability of the general conclusions. On the other hand, they provide information for comparative analysis of the development of the geoecological situation in urban and district SGSs in terms of the effectiveness of the use of development resources.

To illustrate the above, tables 1 and 2 summarize statistical data on the changes in the indexes of statistical parameters of the process, which was studied in time and in SGS.

Urban SGSs are significantly differentiated by changes in the indexes of statistical parameters of the geoecological situation both in terms of the calculated 
periods and in the general result (Table 1). It can be seen that for the whole period under investigation, the largest number of positive changes in the indexes are for Pavlograd (total 49), Novomoskovsk (33), Sinelnikove (1). All other cities have a negative total amount. Its smallest values are for Dnipro (-60), Vilnogirsk (-55), Nikopol (-55), Kam'yanske (-43). These data are quite logically related to the average distribution of urban SGSs on the phase plane, "projection on the OTD" - "deviation from the OTD".
The complete coincidence of the results of the analysis of the trajectory and the changes in the indexes of statistical parameters of the development of the geoecological situation in the SGSs is fundamentally possible only by chance, because in the first case, quantitative analysis is performed, in the second one - qualitative. A similar conclusion can be drawn on the results of comparative analysis in terms of estimated periods.

Table 1. Generalized changes in development parameters indices of geoecological situation development in urban sociogeosystems for estimated periods

\begin{tabular}{|c|c|c|c|c|c|c|c|c|c|c|c|c|c|}
\hline \multirow[b]{2}{*}{$\begin{array}{c}\text { Estimated } \\
\text { periods }\end{array}$} & \multicolumn{13}{|c|}{ Codes of time derivatives of indexes by cities } \\
\hline & 莦 & 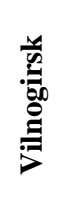 & 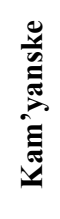 & 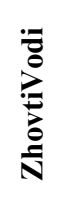 & 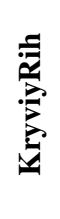 & 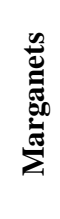 & $\begin{array}{l}\bar{O} \\
\overline{0} \\
\stackrel{y}{\bar{z}}\end{array}$ & 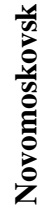 & $\frac{\vec{b}}{\overrightarrow{0}}$ & 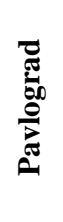 & 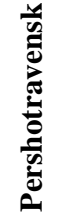 & 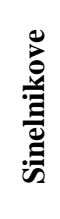 & 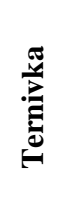 \\
\hline 1 & 3 & 11 & -3 & 6 & -20 & 3 & -20 & 28 & 6 & 38 & 14 & 52 & -14 \\
\hline 2 & 27 & -30 & 32 & -6 & 11 & -2 & 8 & -9 & 12 & 13 & 2 & -5 & -8 \\
\hline 3 & -57 & -64 & -21 & -38 & -54 & -58 & -62 & 16 & -49 & 20 & -55 & -16 & -54 \\
\hline 4 & -33 & 28 & -51 & 7 & 33 & 23 & 19 & -2 & 12 & -22 & 8 & -30 & 38 \\
\hline Sum & -60 & -55 & -43 & -31 & -30 & -34 & -55 & 33 & -19 & 49 & -31 & 1 & -38 \\
\hline
\end{tabular}

Note: Estimated periods: 1 -2013-2014; 2 -2014-2015; 3-2015-2016; 4-2016-2017.

Table 2. Generalized changes in development parameters indices of geoecological situation development in district sociogeosystems for estimated periods

\begin{tabular}{|c|c|c|c|c|c|c|c|c|c|c|c|}
\hline \multirow[b]{2}{*}{$\begin{array}{c}\text { Estimated } \\
\text { periods }\end{array}$} & \multicolumn{11}{|c|}{ Codes of time derivatives of indices by district } \\
\hline & $\begin{array}{l}\frac{3}{0} \\
\frac{1}{2} \\
\frac{1}{0} \\
\frac{0}{2} \\
\frac{0}{4}\end{array}$ & $\frac{\vec{x}}{\overrightarrow{0}}$ & 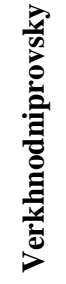 & 葛 & 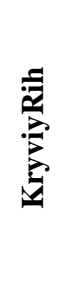 & 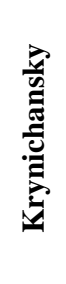 & 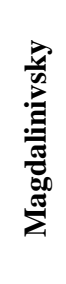 & 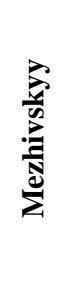 & 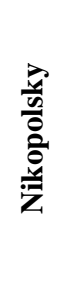 & 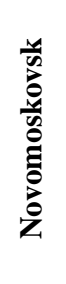 & 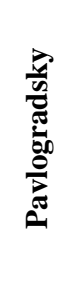 \\
\hline 1 & -26 & 21 & 27 & 13 & 13 & 38 & 7 & 46 & 25 & 40 & -10 \\
\hline 2 & 1 & -9 & -6 & 4 & -5 & -17 & -36 & -13 & -20 & 9 & -34 \\
\hline 3 & -49 & -10 & -22 & 6 & 12 & 13 & 9 & -18 & -32 & -14 & -55 \\
\hline 4 & -28 & 33 & -39 & -11 & 10 & 4 & 3 & 23 & 9 & 21 & -14 \\
\hline Sum & -102 & 35 & -40 & 12 & 30 & 38 & -17 & 38 & -18 & 56 & -113 \\
\hline \multirow[b]{2}{*}{$\begin{array}{l}\text { Estimated } \\
\text { periods }\end{array}$} & \multicolumn{11}{|c|}{ Codes of time derivatives of indices by district } \\
\hline & 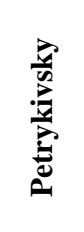 & 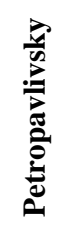 & $\begin{array}{l}\frac{\overrightarrow{0}}{0} \\
\frac{0}{0} \\
\frac{1}{0} \\
0 \\
0\end{array}$ & 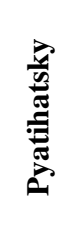 & 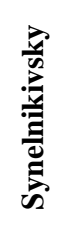 & 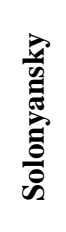 & 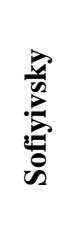 & 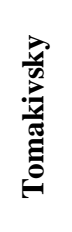 & 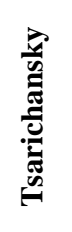 & $\frac{\vec{n}}{0}$ & $\frac{\vec{y}}{0}$ \\
\hline 1 & 46 & -8 & 15 & -3 & 13 & 26 & 22 & 8 & 4 & 37 & 16 \\
\hline 2 & -8 & -11 & -11 & -20 & -32 & -15 & 2 & -20 & -22 & -16 & -22 \\
\hline 3 & -5 & -30 & -20 & -13 & -26 & -30 & -7 & -28 & -18 & -12 & -16 \\
\hline 4 & -4 & -7 & 22 & -14 & 37 & -25 & -16 & 24 & -3 & 27 & -29 \\
\hline Sum & 29 & -56 & 6 & -50 & -8 & -44 & 1 & -16 & -39 & 36 & -51 \\
\hline
\end{tabular}

Note: Estimated periods: 1 -2013-2014; 2-2014-2015; 3-2015-2016; 4-2016-2017. 
The territorial distribution of district SGSs according to the dynamics of changes in the indices of statistical parameters of the geoecological situation is presented in Fig. 1.

District SGSs are further differentiated by the change in the indices of statistical parameters of the development of the geoecological situation compared to urban ones (Table 2, Fig. 1). Thus, there is a much larger scope of the total for the entire period - from the minimum -113 (Pavlogradsky district) to the maximum of 56 (Novomoskovsk district). This indicates that the district SGS study process is more complicated and probably has more features. In the total amount of changes in the indices of statistical parameters of the development of the geoecological situation in the district sociogeosystems, the following are the highest in such areas as Novomoskovsk (56),
Krynichansky (38), Mezhivskyy (38), Shirokivsky (36), Vasylkivsky(35). Positive aggregate amounts are also shown for Dnipro, KryviyRih, Petrykivsky, Pokrovsky and Sofiyivsky districts. The smallest total amounts characterise the following districts: Pavlogradsky (-113), Apostolivsky (-102), Petropavlivsky (-56), Yurievsky (-51), Pyatihatsky $(-50)$. Other areas not listed above are also characterized by negative total sums of change in indices. The statistical analysis of changes in the indexes in terms of settlement periods gives grounds to state that there are quite complex and contradictory time patterns in the development of the geoecological situation in the district SGSs, but in most cases they coincide with the results of modeling the trajectory of the process.

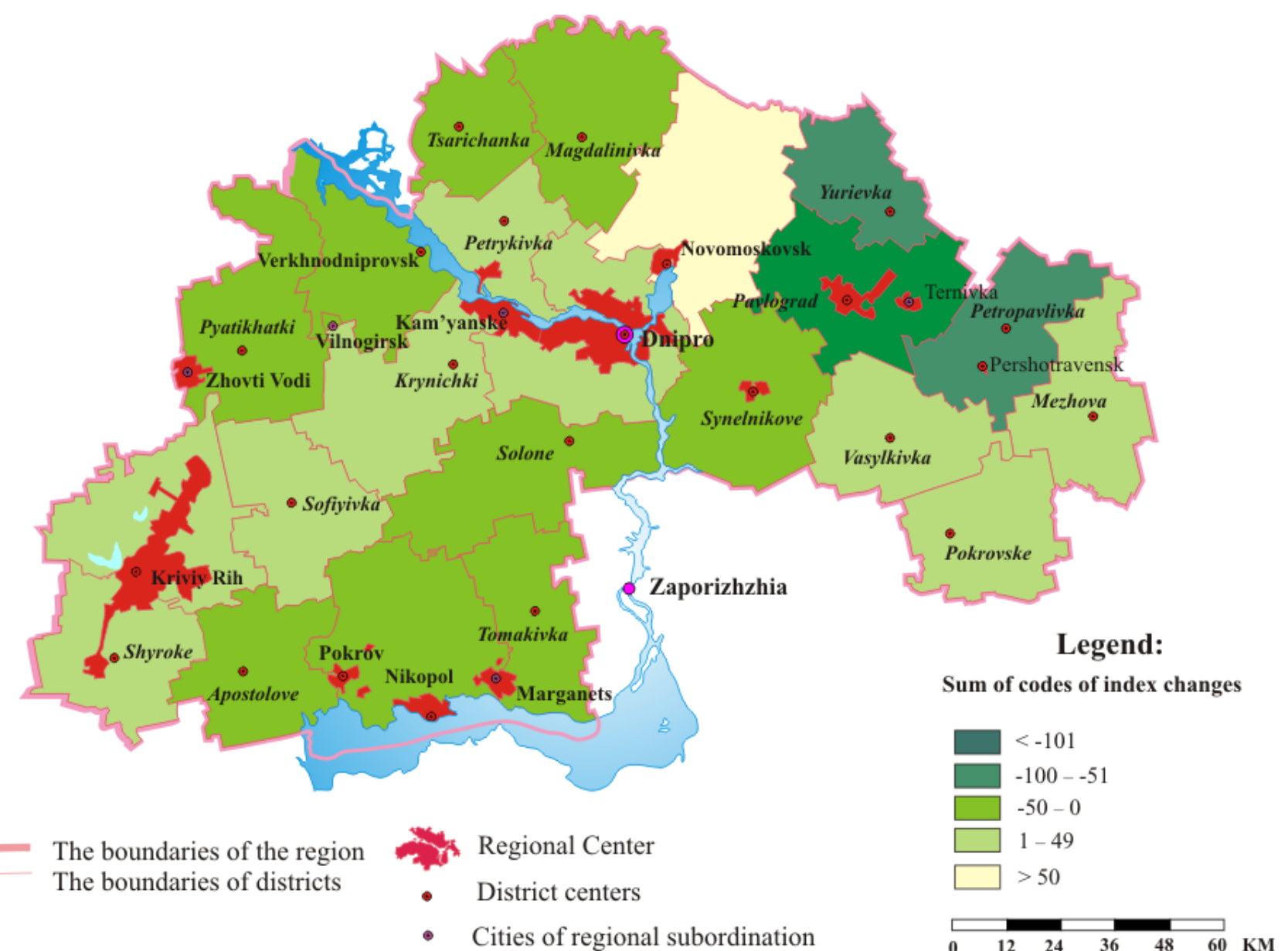

Fig. 1. Distribution of areas according to the dynamics of changes in the index of change of statistical parameters of the development of the geoecological situation.

When comparing the results obtained with the average distribution of district SGSs on the phase plane, "projection on the OTD" - "deviation from the OTD", it can be stated that they mainly confirm the results of the analysis of the trajectory of the investigated process. The exception is the discrepancy between the data for Solonyansky and Yurievsky districts, which, by modeling the trajectory, belong to the group of leaders, while according to the total sum of the index changes they have a worse position. This can be explained by the fact that quantitative changes in the parameters of the development of the geological 
situation in these districts were more intense, as evidenced by the corresponding trajectories of the process.

Dynamics of codes of index of changes of statistical parameters of geoecological situation development in SGSs of the Dnipropetrovsk region can be classified as shown in Table 3.

Recommendations concerning the management of the process of formation and development of the geoecological situation in specific city and district SGSs are reduced to the following. The dynamics of the first three classes do not cause particular concern, as the indices grow and this is a sign of progress in the development of the geoecological situation with the corresponding parameters. The dynamics of grades 4 to 6 are variable in direction and require analysis of the appropriate parameters for translating the development of the geoecological situation behind them in a stable positive direction. Finally, the dynamics of changes in the indexes of 7 - 9 classes reflect their decrease, that is, a steady regression in the development of the geoecological situation with the corresponding parameters. In this case, it is necessary to review the formation of changes in the management of the development of the geoecological situation in these parameters and to make appropriate adjustments to the programs of development of specific SGSs.

From the above, it becomes clear that concrete recommendations for improving the state of the geoecological situation in the cities and districts of the Dnipropetrovsk region can be obtained by analyzing the changes in the indexes of statistical parameters of the development of the geoecological situation in specific SGSs. Such an analysis is performed for all studied SGSs. But due to the limited space within the article, it is impossible to justify here specific recommendations for each of the urban and district SGSs. For a general assessment of the development of the geoecological situation in the SGSs at the level of parameters of this process, that is, the ranking of parameters by efficiency of thecalculated sum of codes of time derivatives of their indices for all SGS. The results are presented in Tables 4 and 5.

Table 3. Classification of development of geoecological situation in sociogeosystems by the criterion of the sum of the codes of changes in the indexes of statistical parameters

\begin{tabular}{|c|c|l|l|}
\hline $\begin{array}{c}\text { Class } \\
\text { number }\end{array}$ & Value of codes & \multicolumn{1}{|c|}{$\begin{array}{c}\text { Dynamic characteristics for the entire } \\
\text { period }\end{array}$} & Changes in the index for the entire period \\
\hline 1 & 4 & Constantly positive & Constantly growing \\
\hline 2 & 3 & Predominantly positive & Predominantly growing \\
\hline 3 & 2 & Positive & Growing \\
\hline 4 & 1 & Limited positive & Limited increase \\
\hline 5 & 0 & Missing & Does not change \\
\hline 6 & -1 & Limited negative & Limitedly reduced \\
\hline 7 & -2 & Negative & Decreasing \\
\hline 8 & -3 & Predominantly negative & Mostly reduced \\
\hline 9 & -4 & Constantly negative & Constantly decreasing \\
\hline
\end{tabular}

Table 4. Ranking of parameters for the effectiveness of the development of the geoecological situation in urban sociogeosystems

\begin{tabular}{|c|c|c|}
\hline Parameter codes & Statistical parameters & $\begin{array}{l}\text { The sum of the codes } \\
\text { of time derivatives }\end{array}$ \\
\hline 4 & $\begin{array}{l}\text { Number of enterprises and organizations of the Unified State Register of } \\
\text { Enterprises and Organizations of Ukraine }\end{array}$ & 38 \\
\hline 25 & Died of external causes & 28 \\
\hline 47 & Waste generation & 22 \\
\hline 87 & Waste generation per $\mathrm{km}^{2}$ & 22 \\
\hline 109 & Waste generation per capita & 22 \\
\hline 23 & Died from respiratory diseases & 21 \\
\hline 61 & Gasoline consumption per $\mathrm{km}^{2}$ & 20 \\
\hline 64 & Gasoline consumption per capita & 20 \\
\hline 18 & Natural increase & 18 \\
\hline 19 & Total dead & 18 \\
\hline 105 & Stationary sources of soot emissions per capita & 18 \\
\hline 17 & Mortality rate & 17 \\
\hline 43 & Emissions of stationary sources of soot & 17 \\
\hline 83 & Emissions of stationary sources of soot per $\mathrm{km}^{2}$ & 17 \\
\hline 24 & Died from diseases of the digestive system & 12 \\
\hline 42 & Emissions of stationary sources of nitric oxide & 12 \\
\hline 67 & Emissions into the atmosphere of stationary sources of gases per $\mathrm{km}^{2}$ & 12 \\
\hline 82 & Emissions of stationary sources of nitric oxide per $\mathrm{km}^{2}$ & 12 \\
\hline 108 & Waste availability per capita & 11 \\
\hline 27 & Emissions to the atmosphere of stationary sources of gases & 10 \\
\hline 89 & Emissions into the atmosphere of stationary sources of gases per person & 10 \\
\hline
\end{tabular}




\begin{tabular}{|c|c|c|}
\hline 36 & Emissions of carbon dioxide & 9 \\
\hline 44 & Emissions of stationary sources of non-methane light organic compounds & 9 \\
\hline 46 & The presence of waste & 9 \\
\hline 60 & Consumption of natural gas per $\mathrm{km}^{2}$ & 9 \\
\hline 76 & Emissions of carbon dioxide per $\mathrm{km}^{2}$ & 9 \\
\hline 84 & $\begin{array}{l}\text { Emissions of stationary sources of non-methane light organic compounds } \\
\text { per } \mathrm{km}^{2}\end{array}$ & 9 \\
\hline 86 & Presence of waste per $\mathrm{km}^{2}$ & 9 \\
\hline 26 & Emissions into the atmosphere, all & 8 \\
\hline 52 & Disease of the respiratory organs & 8 \\
\hline 66 & Emissions into the atmosphere, per $\mathrm{km}^{2}$ & 8 \\
\hline 106 & $\begin{array}{l}\text { Emission of stationary sources of non-methane light organic compounds } \\
\text { per capita }\end{array}$ & 8 \\
\hline 63 & Natural gas consumption per capita & 7 \\
\hline 62 & Consumption of gas oil per $\mathrm{km}^{2}$ & 6 \\
\hline 98 & Emissions of carbon dioxide per capita & 6 \\
\hline 13 & Number of forest fires & 4 \\
\hline 21 & Persons who died of tumors & 4 \\
\hline 22 & Persons who died from circulatory system diseases & 4 \\
\hline 65 & Consumption of gas oil per capita & 4 \\
\hline 57 & Tuberculosis incidence & 3 \\
\hline 15 & Damage from forest fires & 2 \\
\hline 88 & Emissions into the atmosphere, per capita & 2 \\
\hline 104 & Emission of stationary nitrogen oxide sources per capita & 1 \\
\hline 1 & Territory & 0 \\
\hline 11 & Reforestation & 0 \\
\hline 14 & The forest was burnt down & 0 \\
\hline 54 & Disease of the skin & 0 \\
\hline 12 & Planting and seeding of forests & -1 \\
\hline 20 & Persons who died from infectious and parasitic diseases & -1 \\
\hline 35 & Emissions of mobile sources of non-methane light organic compounds & -2 \\
\hline 49 & The incidence of blood and hematopoietic organs & -2 \\
\hline 75 & $\begin{array}{l}\text { Emissions of mobile sources of non-methane light organic compounds } \\
\text { per } \mathrm{km}^{2}\end{array}$ & -2 \\
\hline 97 & $\begin{array}{l}\text { Emission of mobile sources of non-methane light organic compounds per } \\
\text { capita }\end{array}$ & -2 \\
\hline 8 & Gasoline Consumption & -6 \\
\hline 28 & Emissions of mobile sources, total & -6 \\
\hline 32 & Emissions of mobile sources of carbon monoxide & -6 \\
\hline 38 & Emissions of stationary sources of sulfur dioxide & -6 \\
\hline 68 & Emissions of mobile sourcesper $\mathrm{km}^{2}$ & -6 \\
\hline 72 & Emissions of mobile sources of carbon monoxide per $\mathrm{km}^{2}$ & -6 \\
\hline 78 & Emissions of stationary sources of sulfur dioxide per $\mathrm{km}^{2}$ & -6 \\
\hline 90 & Emissions of mobile sources per capita & -6 \\
\hline 94 & Emissions of mobile sources of carbon monoxide per capita & -6 \\
\hline 95 & Emissions of mobile sources of nitrogen oxide per capita & -6 \\
\hline 31 & Emissions of mobile sources of methane & -7 \\
\hline 71 & Emissions of mobile sources of methane per $\mathrm{km}^{2}$ & -7 \\
\hline 33 & Emissions of mobile sources of nitrogen oxide & -8 \\
\hline 59 & HIV / AIDS & -8 \\
\hline 73 & Emissions of mobile sources of nitric oxide per $\mathrm{km}^{2}$ & -8 \\
\hline 93 & Emissions of mobile sources of methane per capita & -8 \\
\hline 6 & Natural gas consumption & -9 \\
\hline 16 & Birth rate & -9 \\
\hline 30 & Emissions of mobile sources of nitrogen dioxide & -10 \\
\hline 53 & Disease of the digestive system & -10 \\
\hline 56 & The morbidity of the genitourinary system & -10 \\
\hline 70 & Emissions of mobile sources of nitrogen dioxide per $\mathrm{km}^{2}$ & -10 \\
\hline 92 & Emissions of mobile sources of nitrogen dioxide per capita & -10 \\
\hline 100 & Emissions of stationary sources of sulfur dioxide per capita & -10 \\
\hline 40 & Emissions of stationary sources of methane & -14 \\
\hline 7 & Gasoline consumption & -14 \\
\hline 55 & Morbidity of the bone and muscular system & -14 \\
\hline 80 & Emissions of stationary sources of methane per $\mathrm{km}^{2}$ & -14 \\
\hline 37 & Emissions of stationary sources, total & -16 \\
\hline 77 & Emission of stationary sources per $\mathrm{km}^{2}$ & -16 \\
\hline
\end{tabular}




\begin{tabular}{|c|l|c|}
\hline 96 & Emissions of mobile soot sources per capita & -16 \\
\hline 102 & Emissions of stationary sources of methane per capita & -16 \\
\hline 29 & Emissions of mobile sources of sulfur dioxide & -17 \\
\hline 34 & Emissions of mobile soot sources & -17 \\
\hline 69 & Emissions of mobile sources of sulfur dioxide per km ${ }^{2}$ & -17 \\
\hline 74 & Emissions of mobile soot sources per km ${ }^{2}$ & -18 \\
\hline 50 & The incidence diseases of the endocrine system & -18 \\
\hline 58 & Incidence of oncology & -18 \\
\hline 91 & Emissions of mobile sources of sulfur dioxide per capita & -18 \\
\hline 99 & Emissions of stationary sources for per capita & -19 \\
\hline 41 & Emissions of stationary sources of carbon monoxide & -19 \\
\hline 81 & Emission of stationary sources of carbon monoxide per km ${ }^{2}$ & -20 \\
\hline 3 & Population density & -20 \\
\hline 103 & Emission of stationary sources of carbon monoxide per capita & -22 \\
\hline 2 & Present population & -22 \\
\hline 38 & Morbidity, total & -31 \\
\hline 79 & Emissions of stationary sources of nitrogen dioxide & -31 \\
\hline 101 & Emissions of stationary sources of nitrogen dioxide per km ${ }^{2}$ & -34 \\
\hline 45 & Emission of stationary sources of nitrogen dioxide per capita & -37 \\
\hline 85 & Emissions of carbon dioxide & -37 \\
\hline 51 & Emissions of carbon dioxide per km ${ }^{2}$ & -38 \\
\hline 107 & The incidence of the blood circulation system & -38 \\
\hline
\end{tabular}

Table 5. Ranking of parameters on the effectiveness of the development of geoecological situation in district sociogeosystems

\begin{tabular}{|c|c|c|}
\hline Parameter codes & Statistical parameters & $\begin{array}{l}\text { The sum of the codes } \\
\text { of time derivatives }\end{array}$ \\
\hline 4 & $\begin{array}{l}\text { Number of enterprises and organizations of the Unified State Register of } \\
\text { Enterprises and Organizations of Ukraine }\end{array}$ & 52 \\
\hline 41 & Emissions of stationary sources of carbon monoxide & 34 \\
\hline 81 & Emission of stationary sources of carbon monoxide per $\mathrm{km}^{2}$ & 34 \\
\hline 25 & Died of external causes & 32 \\
\hline 103 & Emission of stationary sources of carbon monoxide per capita & 32 \\
\hline 16 & Birth rate & 31 \\
\hline 38 & Emissions of stationary sources of sulfur dioxide & 30 \\
\hline 42 & Emissions of stationary sources of nitric oxide & 30 \\
\hline 78 & Emissions of stationary sources of sulfur dioxide per $1 \mathrm{~m}^{2}$ & 30 \\
\hline 82 & Emissions of stationary sources of nitric oxide per $\mathrm{km}^{2}$ & 30 \\
\hline 100 & Emissions of stationary sources of sulfur dioxide per capita & 29 \\
\hline 17 & Mortality rate & 28 \\
\hline 19 & Total dead & 28 \\
\hline 104 & Emission of stationary nitrogen oxide sources per capita & 23 \\
\hline 46 & The presence of waste & 22 \\
\hline 86 & Presence of waste for $\mathrm{km}^{2}$ & 22 \\
\hline 43 & Emissions of stationary sources of soot & 21 \\
\hline 83 & Emissions of stationary sources of soot per $\mathrm{km}^{2}$ & 21 \\
\hline 22 & Died from circulatory system diseases & 20 \\
\hline 24 & Died from diseases of the digestive system & 20 \\
\hline 57 & Tuberculosis incidence & 20 \\
\hline 65 & Consumption of gas oil per capita & 20 \\
\hline 108 & Waste availability per capita & 19 \\
\hline 105 & Stationary sources of soot emissions per capita & 15 \\
\hline 58 & Incidence of oncology & 14 \\
\hline 8 & Gasoline Consumption & 13 \\
\hline 62 & Consumption of gas oil per $\mathrm{km}^{2}$ & 13 \\
\hline 23 & Died from respiratory diseases & 12 \\
\hline 39 & Emissions of stationary sources of nitrogen dioxide & 12 \\
\hline 79 & Emissions of stationary sources of nitrogen dioxide $\mathrm{km}^{2}$ & 12 \\
\hline 3 & Population density & 11 \\
\hline 21 & Died from tumors & 10 \\
\hline 63 & Natural gas consumption per capita & 10 \\
\hline 13 & Number of forest fires & 9 \\
\hline 47 & Waste generation & 8 \\
\hline 87 & Waste generation per $\mathrm{km}^{2}$ & 8 \\
\hline 40 & Emissions of stationary sources of methane & 7 \\
\hline 80 & Emissions of stationary sources of methane per $\mathrm{km}^{2}$ & 7 \\
\hline
\end{tabular}




\begin{tabular}{|c|c|c|}
\hline 101 & Emission of stationary sources of nitrogen dioxide per capita & 6 \\
\hline 14 & The forest was burnt out & 4 \\
\hline 15 & Damage from forest fires & 4 \\
\hline 44 & Emissions of stationary sources of non-methane light organic compounds & 4 \\
\hline 84 & $\begin{array}{l}\text { Emissions of stationary sources of non-methane light organic compounds } \\
\text { per km }\end{array}$ & 4 \\
\hline 109 & Waste generation per capita & 2 \\
\hline 1 & Territory & 0 \\
\hline 56 & Morbidity of the genitourinary system & 0 \\
\hline 6 & Natural gas consumption & -1 \\
\hline 45 & Emissions of carbon dioxide & -1 \\
\hline 60 & Natural gas consumption per $\mathrm{km}^{2}$ & -1 \\
\hline 85 & Emissions of carbon dioxide per $\mathrm{km}^{2}$ & -1 \\
\hline 49 & The incidence of diseases of the blood and hematopoietic organs & -2 \\
\hline 106 & $\begin{array}{l}\text { Emission of stationary sources of non-methane light organic compounds } \\
\text { per capita }\end{array}$ & -2 \\
\hline 32 & Emissions of mobile sources of carbon monoxide & -4 \\
\hline 35 & Emissions of mobile sources of non-methane light organic compounds & -4 \\
\hline 51 & The incidence of the blood circulation system & -4 \\
\hline 72 & Emissions of mobile sources of carbon monoxide per $\mathrm{km}^{2}$ & -4 \\
\hline 75 & $\begin{array}{l}\text { Emissions of mobile sources of non-methane light organic compounds } \\
\text { per km }\end{array}$ & -4 \\
\hline 107 & Emissions of carbon dioxide per capita & -4 \\
\hline 28 & Emissions of mobile sources, total & -6 \\
\hline 31 & Emissions of mobile sources of methane & -6 \\
\hline 37 & Emissions of stationary sources, total & -6 \\
\hline 55 & Morbidity of the bone and muscular system & -6 \\
\hline 68 & Emissions of mobile sources for $1 \mathrm{~km}^{2}$ & -6 \\
\hline 71 & Emissions of mobile sources of methane per $1 \mathrm{~km}^{2}$ & -6 \\
\hline 77 & Emissions of stationary sources per $1 \mathrm{~km}^{2}$ & -6 \\
\hline 94 & Emissions of mobile sources of carbon monoxide per capita & -6 \\
\hline 97 & $\begin{array}{l}\text { Emission of mobile sources of non-methane light organic compounds per } \\
\text { capita }\end{array}$ & -6 \\
\hline 11 & Reforestation & -7 \\
\hline 12 & Planting and seeding forest & -7 \\
\hline 59 & HIV / AIDS & -8 \\
\hline 102 & Emissions of stationary sources of methane per capita & -8 \\
\hline 90 & Emissions of mobile sources per capita & -10 \\
\hline 93 & Emissions of mobile methane sources per capita & -10 \\
\hline 20 & Died from infectious and parasitic diseases & -12 \\
\hline 52 & Disease of the respiratory organs & -12 \\
\hline 99 & Emissions of stationary sources per capita & -12 \\
\hline 54 & Disease of the skin & -14 \\
\hline 67 & Emissions into the atmosphere of stationary gas sources per $\mathrm{km}^{2}$ & -17 \\
\hline 27 & Emissions to the atmosphere of stationary gas sources & -18 \\
\hline 33 & Emissions of mobile sources of nitrogen oxide & -18 \\
\hline 48 & Morbidity, total & -18 \\
\hline 50 & The incidence of the endocrine system & -18 \\
\hline 73 & Emissions of mobile sources of nitric oxide per $\mathrm{km}^{2}$ & -18 \\
\hline 53 & Disease of the digestive system & -20 \\
\hline 26 & Emissions into the atmosphere, all & -26 \\
\hline 66 & Emissions into the atmosphere per $\mathrm{km}^{2}$ & -26 \\
\hline 30 & Emissions of mobile sources of nitrogen dioxide & -27 \\
\hline 36 & Emissions of carbon dioxide & -27 \\
\hline 70 & Emissions of mobile sources of nitrogen dioxide per $\mathrm{km}^{2}$ & -27 \\
\hline 76 & Emissions of carbon dioxide per $\mathrm{km}^{2}$ & -27 \\
\hline 29 & Emissions of mobile sources of sulfur dioxide & -29 \\
\hline 69 & Emissions of mobile sources of sulfur dioxide per $\mathrm{km}^{2}$ & -29 \\
\hline 34 & Emissions of mobile soot sources & -32 \\
\hline 74 & Emissions of mobile soot sources per $\mathrm{km}^{2}$ & -32 \\
\hline 89 & Emissions into the atmosphere of stationary sources of gases per capita & -32 \\
\hline 91 & Emissions of mobile sources of sulfur dioxide per capita & -32 \\
\hline 64 & Gasoline consumption per capita & -34 \\
\hline 92 & Emissions of mobile sources of nitrogen dioxide per capita & -34 \\
\hline 96 & Emissions of mobile soot sources per capita & -36 \\
\hline 88 & Emissions into the atmosphere per capita & -38 \\
\hline
\end{tabular}


V.V. Hrushka, N.A. Horozhankina,

\begin{tabular}{|c|l|c|}
\hline 95 & Emissions of mobile sources of nitrogen oxide per capita & -38 \\
\hline 18 & Natural increase of population & -41 \\
\hline 98 & Emissions of carbon dioxide per capita & -46 \\
\hline 7 & Gasoline consumption & -51 \\
\hline 61 & Gasoline consumption per sq. km & -51 \\
\hline 2 & Present population & -58 \\
\hline
\end{tabular}


Conclusions and recommendations. The effectiveness of the parameters of the geoecological situation in urban and district SGSs is different. Thus, of the fifteen indices that have the highest sum of the codes of change for urban and district SGSs, only three correspond to the parameters: number of enterprises and organizations of the Unified State Register of Enterprises and Organizations of Ukraine, the mortality rate (decreasing) and the total number of dead (decreasing). Of the fifteen indices with the lowest sums of change codes, one corresponds to the parameter of the number of the existing population (decreasing over time). This is another argument concerning the significant differences in the conditions of the development of the geoecological situation in the cities and districts of the Dnipropetrovsk region.

Investigation of the specificity of the development of the geoecological situation in urban sociogeosystems led to the following conclusions: the most specific conditions for the formation of the geoecological situation exist in the cities of Kryvyi Rih, Nikopol, Kam'yanske and, in part, Dnipro, which have the most developed industry. Among the areas according to the specificity of the geoecological situation, Apostolivsky district is clearly distinguished, which has the worst indicators for other types of analysis. Partially different from other areas under the conditions of development of the geo-ecological situation are Pavlogradsky, Dnipro, Petropavlivsky and KryvyiRih districts.

The analysis of changes in the indices of statistical parameters of the geoecological situation for each city and district SGS has allowed us to group the parameters by the frequency of positive and negative changes. The tables show the sum of the codes of parameters index changes for each SGS, which makes it possibleto purposefully manage the process of formation and development of the geoecological situation in the SGSs. A similar analysis was carried out for all parameters of the development of the geoecological situation, which showed that according to the dynamics of the indices, they differ significantly for cities and districts.

\section{References}

Mashkov, O. A., Niemets, K. A., 2010. Grafoanality`chny`j metod bagatovy mirnoyi klasy` fikaciyisuspil`nogeografichny`x ob'yektiv [Graphophone method of multidimensional classification of social and geographical objects].Inter-regional journal «Human Geography Journal». - Harkiv: HNU named after V.N.Karazin, Issue 8(1), 30-35 (in Ukrainian).

Niemets, K., Grushka V., 2014. Komponentny`j analiz vektoru rozvy`tku sociogeosystem [Component analysis of the vector of sociogeosystem development]. Inter-regional journal «Human Geography Journal». - Harkiv: HNU named after V.N. Karazin, Issue 16 (1), 7-15 (in Ukrainian).

Niemets, K. A., Niemets L. M., 2011. Problemy` doslidzhennya staropromy`slovy`x regioniv Ukrayiny` yak skladovy`x nacional'noyi sociogeosy`stemy` [Problems of research of the old industrial regions of Ukraine as components of the national sociogeosystem]. Socio-Physical-Geographic and Geo-Ecological Problems of Old-Industrial Districts: Materials of the All-Ukrainian Scientific and Practical Conference devoted to the 75th anniversary of the formation of the Department of Geography of the Lugansk Taras Shevchenko National University (Lugansk, October 17-19, 2011). - Lugansk: Publishing House «DZ LNU named after Taras Shevchenko», 23-27 (in Ukrainian).

Niemets, K. A., 2009. Modeljuvannja trajektorii' rozvytku regional'nyh sociogeosystem Ukrai'ny [Modeling of the trajectory of regional sociogeosystems in Ukraine]. Inter-regional journal «Human Geography Journal». - Harkiv: HNU named after V.N. Karazin, Issue 7 (2), 66-81 (in Ukrainian).

Shablij, O. I, 1994.Matematy`chni metody` v social`no-ekonomichnij geografiyi [Mathematical methods in socioeconomic geography]. - Lviv: Svit, 304. (in Ukrainian).

Shy`yan, D.V., 2012. Tery`torial’ni osobly`vosti zaxvoryuvanosti naselennya m. Kry`vy`j Rig yak centru staropromy`slovogo regionu [Territorial features of the morbidity of the population of the city of Kryvy Rih as the center of the old industrial region]. Thesis of Candidate of Geographic Sciences (in Ukrainian).

Golovne upravlinnya staty`sty ky` u Dnipropetrovs kij oblasti, 2018 [Main Department of Statistics in Dnipropetrovsk Region]. Retrieved from URL: http://www.dneprstat.gov.ua (in Ukrainian).

Dnipropetrovs`ka oblasna sanitarno-epidemiologichna stanciya, 2018 [Dnipropetrovsk Regional Sanitary and

Epidemiological Station]. Retrieved from U RL:http://www.sesobl.dp.ua 